may be related to the above-mentioned elevation of the intra-mitochondrial ATP-level, ultimately responsible for the respiratory inhibition.

Since, as previously reported, hexokinase in the resting liver has a low affinity for glucose, it may be suggested, as a working hypothesis, that a temporary incroase of such an affinity during regeneration may both stimulate the ærobic glycolysis rate and favour the appearance of a Crabtree effect.

\section{E. Clerici}

P. CtCcarone

Istituto di Patologia Generale,

Università di Milano, Italy.

${ }^{1}$ Ibsen, K. H., Cancer Res., 21, 829 (1961).

'Di Pietro, D. L., Sharma, C., and Weinhouse, S., Biochem., 1, 455 (1962).

${ }^{3}$ Guidotti, G., Clerici, E., and Bazzano, E., Min. Nucleare, 2, 14 (1958).

‘ Higgins, G. M., and Anderson, R. M., Arch. Path., 12, 186 (1931).

- Clerici, E., Guidotti, G., Sambo, G., and Bazzano, E., Proc. Soc. Exp. Biol. Med., 105, 377 (1960).

- Packer, L., and Golder, R. H., J. Biol. Chem., 235, 1234 (1960).

${ }^{7}$ Areos, J. C., Gosch, H. H., and.Zickafoose, D., J. Biophys. Biochem. Cytol., 10, 23 (1961).

\section{$\beta-D-G l u c o s i d u r o n i c$ Acid Conjugation by the Mucosa of Various Organs}

B-D-GLUCOSIDURONIC acid synthesis carried out by the mucosal membrane of the stomach and intestine has been previously demonstrated ${ }^{1-4}$. This function is strongest in the duodenum. The mechanism of this $\beta$-D-glucosiduronic acid conjugation is the same as in the liver; uridinediphosphoglucosiduronic acid acts as a glucuronic acid donator; this is oxidated by a specific dehydrogenase enzyme system and the final transfer of glucuronic acid is carried out by specific glucuronyl transferase enzymes.

The glucosiduronic conjugation of $o$-aminophenol has been tested also with mucosa of other organs in the rabbit, rat and guinea pig with negative results. Only a trace reaction occurs with the bladder mucosa ${ }^{2,3}$. The cat has been an exception to the usual findings : no organ in the cat reveals a positive glucosiduronic acid conjugation capacity ${ }^{3,6}$.

It was expected that the $\beta$-D-glucosiduronic acid conjugation might occur also at the higher parts of the gastrointestinal tract. Therefore, experiments were performed in which the conjugation eapacity of the oral mucosa slices in the rabbit, guinea pig, rat and dog were determined. Control analyses were also made using liver and skeletel muscle samples. Also the gall bladder, conjunctiva and vaginal mucosa were tested in guinea pig. The results are presented in Table 1. It can be seen that, with the exception of dog, all animals showed a glucosiduronic acid conjugation capacity in the upper part of the gastrointestinal tract. This capacity was highest in the guinea pig and lowest in the rabbit. In the rat (Wistar) the conjugation capacity increased beyond the cesophagus up to the duodenum, whereafter it decreased again. Different parts of the stomach showed no difference in this capacity. It is interesting to note that the gall bladder, and to some extent also the vagina, possess a conjugation capacity.

In addition to these observations, trials were made in order to establish a comparison of the conjugation capacity of the gastric and intestinal wall with the liver. Altogether 80 male and female rats were used. The conjugation capacity of the liver, lesser and major curvature of the stomach, pylorus, duodenum, jejunum, ileum and colon were analysed using whole tissue slices and $o$-aminophenol as the substrate. The method has been previously described $^{3}$. The results are listed in Table 2. They also reveal the activity of the renal cortex and medulla without any difference between these two organs.

These results indicate that the $\beta$-D-glucosiduronic acid conjugation is really carried out by the whole gastro-

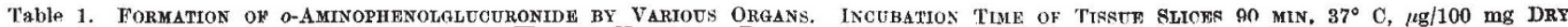
WEIGHT. NUMBER OF DETERMINATIONS (IN BRA (EETS)

\begin{tabular}{|c|c|c|c|c|c|c|c|}
\hline \multirow[b]{2}{*}{$\begin{array}{l}\text { Organ } \\
\text { Anterior part of the tongue } \\
\text { Posterior part of the tongue } \\
\text { Bottom of the tongue } \\
\text { Tongue muscle } \\
\text { Cheek mucosa } \\
\text { Gsophagus mucosa, upper part } \\
\text { Skeletal muscle lower part } \\
\text { Gall bladder mucosa } \\
\text { Vaginal mucosa } \\
\text { Eye conjunctiva } \\
\text { Liver } \\
\text { Duodenum }\end{array}$} & \multicolumn{2}{|c|}{ male $\stackrel{\text { Guinea pig }}{\text { female }}$} & \multirow{2}{*}{$\begin{array}{l}\quad \text { Dog } \\
\text { trace } \\
\text { trace } \\
\text { trace } \\
\text { negative } \\
\text { trace } \\
\text { trace }\end{array}$} & \multicolumn{2}{|c|}{$\begin{array}{l}\text { Rabbit female } \\
\text { fer }\end{array}$} & \multicolumn{2}{|c|}{ Rat female } \\
\hline & $\begin{array}{c}136 \pm 43(6) \\
133 \pm 51(6) \\
70 \pm 22(6) \\
23 \pm 15(6) \\
216 \pm 82(6) \\
284 \pm 101(6) \\
\text { negative }\end{array}$ & $\begin{array}{l}79 \pm 57(2) \\
71 \pm 51(2) \\
38 \pm 26(2) \\
66 \pm 53(2) \\
43 \pm 37(2) \\
\text { negative } \\
59 \pm 19(5) \\
\text { trace } \\
\text { trace } \\
156 \pm 115(2)\end{array}$ & & $\begin{array}{l}21 \pm 9 \cdot 4(5) \\
21+9 \cdot 6(5) \\
16 \pm 6 \cdot 3(7) \\
28 \pm 9 \cdot 4(12) \\
14 \pm 8 \cdot 4(5) \\
\text { negative }\end{array}$ & $\begin{array}{l}26 \pm 13(4) \\
21 \pm 7 \cdot 0(4) \\
39 \pm 20(4) \\
\text { trace } \\
30 \pm 15(4) \\
27 \pm 14(4) \\
\text { negative }\end{array}$ & $\begin{array}{l}48 \pm 22(3) \\
44 \pm 27(4) \\
81 \pm 39(4) \\
14 \pm 8 \cdot 8(4) \\
67 \pm 31(4) \\
14 \pm 6 \cdot 9(2) \\
91 \pm 41(4) \\
\text { negative }\end{array}$ & $\begin{array}{r}79 \pm 43(4) \\
27 \pm 11(4) \\
65 \pm 29(4) \\
16 \pm 10(4) \\
91 \pm 50(4) \\
76 \pm 37(4) \\
167+69(4)\end{array}$ \\
\hline
\end{tabular}

Table 2. Formation of o-AMINophenolghteUroside by Various Rat ORGATS. INCUBATION TIMF OF TISSUE SLIOES 90 MIN, $37^{\circ} \mathrm{C}$

\begin{tabular}{|c|c|c|c|}
\hline Organ & Series I & \multicolumn{2}{|c|}{ Series II } \\
\hline Male & $\begin{array}{l}\mu \mathrm{g} / 100 \mathrm{mg} \\
\text { dry weight }\end{array}$ & $\begin{array}{l}\mu \mathrm{g} / 100 \mathrm{mg} \\
\mathrm{dry} \text { weight }\end{array}$ & $\underset{\text { nitrogen }}{\mu \mathrm{g} / \mathrm{mg}}$ \\
\hline 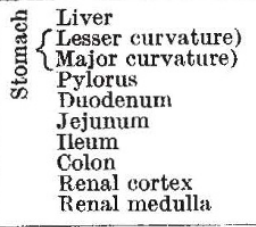 & $\begin{array}{l}153 \pm 32 \\
60 \pm 5 \\
44 \pm 6 \\
103 \pm 29 \\
249 \pm 23 \\
172 \pm 17 \\
52 \pm 7 \\
55 \pm 5 \\
58 \pm 8 \\
41 \pm 8\end{array}$ & $\begin{aligned} 64 & \pm 6 \\
25 & \pm 3 \\
24 & \pm 5 \\
41 & \pm 4 \\
125 & \pm 11 \\
76 & \pm 11 \\
21 & \pm 3 \\
27 & \pm 2 \\
34 & \pm 2 \\
7 & \pm 1\end{aligned}$ & $\begin{array}{l}180 \pm 34 \\
129 \pm 19 \\
106 \pm 15 \\
288 \pm 35 \\
860 \pm 52 \\
565 \pm 36 \\
206 \pm 30 \\
305 \pm 165 \\
124 \pm 38 \\
77 \pm 24\end{array}$ \\
\hline \multicolumn{4}{|l|}{ Female } \\
\hline $\begin{array}{l}\text { Liver } \\
\text { İ: } \\
\text { Lesser curvatiure) } \\
\text { Major curvature) } \\
\text { Pylorus } \\
\text { Duodenum } \\
\text { Jejunum } \\
\text { Ileum } \\
\text { Colon } \\
\text { Renal cortex } \\
\text { Renal medulla }\end{array}$ & $\begin{array}{l}90 \pm 9 \\
54 \pm 9 \\
41 \pm 5 \\
75 \pm 9 \\
221 \pm 25 \\
181 \pm 25 \\
50 \pm 8 \\
41 \pm 5 \\
50 \pm 5 \\
57 \pm 10\end{array}$ & $\begin{aligned} 58 & \pm \\
27 & \pm 3 \\
23 & \pm 2 \\
36 & \pm \\
115 & \pm 11 \\
64 & \pm 6 \\
25 & \pm 4 \\
29 & \pm 3 \\
30 & \pm \\
15 & \pm 2\end{aligned}$ & $\begin{array}{l}135+16 \\
127 \pm 13 \\
88 \pm 9 \\
231 \pm 17 \\
561 \pm 73 \\
367 \pm 36 \\
171 \pm 22 \\
158 \pm 16 \\
82 \pm 8 \\
(273 \pm 86)\end{array}$ \\
\hline
\end{tabular}

intestinal tract. Sex differences demonstrated by other workers ${ }^{7}$ could not be detected in the Wistar rats used here, which agrees with our other study. This might be explained by strain specificity. On the other hand, a great difference is noted between conjugation-level in series I and II. It happens that the former was performed in the winter and tho latter in the spring. Whether the seasonal factors really account for the results needs further investigation.

This work was supported by a grant from the Sigrid Juselius Foundation.

K. J. W. Hartiala

M. O. PULKKINEN

Department of Physiology,

P. SAvola

University of Turku, Finland.

'Zini, F., Sperimentale, 102, 40 (1952)

${ }^{3}$ Hartiala, K. J. W., Acta physiol. Scand.. 31. suppl. 114, 20 (1954)

${ }^{3}$ Hartiala, K. J. W., Ann. Exp. Med. Fenniue, 33, 239 (1955).

4 Shiray, Y., and Ohkubo, T., J. Biochem. (Tokyo), 41, 341 (1954).

- Stevenson, I. H. and Dutton, G. J., Biochem. J. 82, 330 (1962).

'Hartiala, K. J. W., Biochem. Pharm., B, 82 (1961).

' Hartiala, K. J. W., Biochem. Pharm., 6, 82 (1961). 